\title{
ANÁLISE DOS RECURSOS DIDÁTICOS OFERECIDOS AO ENSINO FUNDAMENTAL EM FORMA DE PESQUISA E EXTENSÃO
}

ANALYSIS OF THE TEACHING TECHNIQUE RESOURCES OFFERED TO THE

ELEMENTARY SCHOOL SYSTEM IN THE FORM OF RESEARCH AND EXTENSION

\author{
Bruna da Silva Kuhnen ${ }^{1}$ \\ Elen Souza dos Santos ${ }^{1}$ \\ Jamille Torres Gonçalves ${ }^{1}$ \\ Maiuli Neves Antunes Benincá ${ }^{1}$
}

\begin{abstract}
RESUMO
Neste trabalho as acadêmicas do curso de Ciências Biológicas Licenciatura da Universidade do Extremo Sul Catarinense (UNESC) realizaram uma pesquisa com alunos e equipe pedagógica de uma rede particular de ensino fundamental na cidade de Criciúma, com o intuito de observar como as didáticas diferenciadas em escolas podem torna-se um diferencial na aprendizagem, uma vez que os recursos didáticos são ferramentas responsáveis para dinamizar o trabalho em sala de aula, tornando-se uma ferramenta de grande valia.

Após o levantamento de dados com a pesquisa, houve a realização da segunda etapa do projeto, a extensão, a qual tinha como objetivo utilizar didáticas diferenciadas para se trabalhar a temática "Alimentação Saudável”, fugindo das práticas tradicionais, a qual é explicada por Libâneo (2003, p. 8-9) como "o professor só passa a matéria e o aluno recebe e reproduz mecanicamente o que absorve".
\end{abstract}

Palavras-chave: Didática; Recursos Didáticos; Ensino; Pesquisa; Extensão.

\begin{abstract}
The students studying Biological Sciences at Universidade do Extremo Sul de Santa Catarina (UNESC) conducted research with the students and teaching staff of a private network elementary school in the city of Criciúma. The research aims to observe how different types of teaching in schools can make a difference in the learning process, since these teaching techniques are valuable tools responsible for boosting productivity in the classroom.

Following the collection of research data, the second stage of the project, the extension, began and aimed to use differentiated teaching to explore the theme of healthy eating. This approach escapes from traditional practices, explained by Libaneo( 2003 p.8,9 ), "the teacher only transmits the subject while the student receives it and proceeds to mechanically reproduce what they have absorbed."
\end{abstract}

Keywords: Teaching techniques, teaching resources, education, research, extension

\footnotetext{
${ }^{1}$ Acadêmicas do curso de Ciências Biológicas da UNESC.
} 


\section{INTRODUÇÃO}

Há muito tempo se é discutido o nível de qualidade do ensino do Brasil, e os fatores cujos quais poderiam trazer melhorias para este setor. No entanto, as deficiências em geral continuaram a ter participação nas escolas. Conforme Antunes (2008, p. 15) "há trinta anos o professor era o centro do processo de ensino e o aluno apenas um receptor de saberes que, aula a aula ia acumulando. Quem não acumulava o suficiente poderia ser corrigido com um castigo ou reprovação".

Hoje, este tipo de metodologia ainda esta presente em muitas escolas, que continuam conduzindo o ensino da mesma forma. A qualificação do quadro docente é uma das deficiências que colaboram para a utilização deste método, e a melhoria neste seguimento é de fundamental importância. De acordo com Vera Maria Candau (2002, p. 13) "a qualidade das aprendizagens dos alunos depende da qualidade do desempenho profissional dos professores e essa qualidade, no geral, tem sido extremamente precária".

Com o passar dos anos, ainda se é desenvolvido a prática de ensino baseada em livros didáticos, sem a utilização de recursos diferenciados, até mesmo no ensino de Ciências, uma das bases científicas para a compreensão da vida. Segundo Demétrio Delizoicov (2002, p. 37) "como forma de metodologia para o ensino de Ciências, há livros didáticos produzidos por pesquisadores da área, mas, no entanto, o professor não pode ser refém dessa única fonte, por melhor que venha a tornar-se sua qualidade".

O professor, como principal fonte de ensino, deve criar condições, viabilizar formas de ação para o aluno aprender e, sobretudo, deve veicular o conhecimento explorado em aula com práticas que despertem o interesse do aluno ao saber científico. Segundo Demétrio Delizoicov (2002, p. 153):

Tornar a aprendizagem dos conhecimentos científicos em sala de aula num desafio prazeroso é conseguir que seja significativa para todos, tanto para o professor quando para o conjunto de alunos que compõe a turma. É transformá-la em um projeto coletivo em que a aventura da busca do novo do desconhecido de sua potencialidade de seus riscos e limites seja a oportunidade para o exercício de aprendizado das relações sociais e dos valores.

Não é apenas o professor que deve vivenciar esta busca em despertar o interesse científico do aluno. As escolas de maneira geral têm plena importância neste processo. Devem planejar-se quanto à estrutura para viabilizar ambientes que fujam da sala de aula e que insiram o aluno num contexto diferenciado, não desvinculando o processo de ensino/aprendizagem de ambientes como laboratórios, saída a campo, atividades de 
estímulo competitivo e científico, exposições, palestras, acervo atualizado, entre outros meios que articulem os conhecimentos oferecidos em sala de aula com práticas que possibilitam maior interesse. Como mencionado por Lima (2006), uma das dificuldades enfrentadas pelos professores e pelos alunos na construção do saber é a falta de metodologias que promovam a mesma, acompanhada por problemas de âmbito familiar e muitas vezes a defasagem na estrutura da escola.

Desta forma, o professor deve atualizar-se frente à ciência, mesmo na falta de instrumentos de trabalho, para informar o aluno dos acontecimentos ao seu redor. De acordo com Lima (2006), o professor de Ciências precisa cada vez mais atualizar-se em relação às descobertas tecnológicas e científicas que constantemente evoluem e são inseridas no cotidiano, trazendo-as ao alcance dos alunos. Assim, o professor deve dedicar-se o máximo possível para se embasar teórica e metodicamente sobre os avanços.

As defasagens na educação causada por ambas às partes, escola e professor, justificam a necessidade que se tem para um olhar mais amplo no desenvolvimento científico. Há tempos formam-se alunos no ensino básico através de métodos retrógrados, que os desmotivam. Como explica Freire (1996, p. 112),

O educador e a educadora crítica não podem pensar que, a partir do curso que coordenam ou do seminário que lideram, podem transformar o país. Mas podem demonstrar que é possível mudar. E isto reforça nele ou nela a importância de sua tarefa político-pedagógica.

Somente com mudanças nos métodos antigos de educar e com a aplicação de atividades de exploração do conhecimento e da pesquisa, que a educação irá ser capaz de concretizar-se como agente de transformação, formando cidadãos críticos, ativos na sociedade, conscientes e atualizados com o que se passa ao seu redor.

\section{OBJETIVO}

Analisar os recursos didáticos utilizados no ensino fundamental, bem como a prática pedagógica e o interesse dos professores e alunos pelo processo de ensino aprendizagem, proporcionando através de pesquisa e extensão a melhoria no ensino. 


\section{METODOLOGIA}

\section{Metodologia da coleta de dados}

Com o intuito de conhecer a realidade pedagógica e estrutural da escola, decidiuse pela realização de uma pesquisa qualitativa que possibilitasse a constatação das necessidades, dificuldades e interesses da comunidade escolar para posteriormente elaborar um projeto de extensão.

A pesquisa e a extensão envolveram a professora responsável pela disciplina de Ciências, a equipe técnica pedagógica e as turmas de sexto e sétimo ano do ensino fundamental, totalizando cinquenta e sete alunos, sendo vinte e dois alunos da turma do sexto ano e trinta e cinco alunos da turma de sétimo ano, as quais, no sétimo ano, responderam somente trinta e três alunos, devido à falta no dia da aplicação do questionário.

Como instrumento de coleta de dados foi aplicado um questionário aos alunos e uma entrevista com a professora e equipe técnica pedagógica, além da observação da infraestrutura da escola e dos recursos didáticos oferecidos e metodologias que despertariam maior interesse pela disciplina.

O questionário referente aos alunos continha oito perguntas objetivas com respectivamente de duas a cinco opções para serem assinaladas. As perguntas foram elaboradas com o intuito de obter informações referentes à estrutura interna da escola e a sua utilização, a linguagem da professora, a utilização de atualidades e recursos bibliográficos, recursos didáticos que melhoram o aprendizado, atividades interdisciplinares e temáticas de interesse para a realização do projeto.

Com relação à equipe técnica pedagógica e a professora, realizou-se uma entrevista com vinte perguntas, para obtenção de dados a respeito da qualificação profissional, participação no PPP, infraestrutura, produção de materiais didáticos, disponibilidade de equipamentos, métodos de avaliação, projetos interdisciplinares, participação dos alunos, assuntos restritos e projetos de integração social.

Durante o período de observação na escola, evidenciou-se a faixa etária dos alunos, interesse, participação, autodisciplina, assiduidade, pontualidade, receptividade, respeito, vocabulário, sensibilidade e relacionamento entre alunos e professora. 


\section{Metodologia da extensão}

A extensão do projeto foi desenvolvida durante três semanas seguidas, nas quintas-feiras dos dias 22 e 29 de maio e 05 de junho do ano de 2014, no horário das 07h30min às $11 \mathrm{~h} 45 \mathrm{~min}$. Trabalhou-se a temática alimentação com uma turma de $6^{\circ}$ ano e $7^{\circ}$ ano, de modo a aplicar na prática as deficiências observadas com a pesquisa realizada.

As atividades realizadas foram fracionadas da seguinte forma:

- Sexto ano

- Palestra sobre alimentação com exposição de vídeo e dinâmica.

- Jogo da cadeia alimentar.

- Construção do conhecimento sobre os cinco sentidos a partir de experimentação.

- Sétimo ano

- Palestra sobre alimentação com exposição de vídeo e dinâmica.

- Gincana de perguntas e respostas.

- Atividade sobre embalagens e rótulos e construção de um cardápio saudável.

\section{RESULTADOS E DISCUSSÕES}

\section{Resultados da pesquisa}

O projeto de pesquisa e extensão foi iniciado através da aplicação de um questionário com os alunos e entrevista com a professora de Ciências e a equipe técnica pedagógica, com o intuito de definir temas de interesse de aprendizagem no ensino de Ciências, deficiências observadas por eles na infraestrutura e metodologias que despertariam o interesse pela disciplina.

A pesquisa foi iniciada com uma entrevista direcionada à professora de Ciências, com o objetivo de conhecer a sua formação acadêmica e situações vivenciadas ao lecionar, abordando algumas questões que abrangem rotinas pedagógicas em sala de aula, as quais ajudariam analisar através das respostas a situação do ensino de Ciências na escola trabalhada.

Como aspecto positivo, dentro da análise das respostas da professora, pode-se destacar que a mesma traz materiais didáticos diferenciados para a sala de aula e, como resultado, possui alunos mais dinâmicos e participativos. Outro ponto positivo é a 
abertura que a escola disponibiliza para a realização de campanhas da saúde e de conscientização.

Verificamos também que para o ensino de Ciências a infraestrutura da escola poderia ser melhorada, uma vez que não existe um espaço próprio para a disciplina, apenas especificamente para outras. Este dado também foi apontado durante as observações do cotidiano da escola e na pesquisa realizada com os alunos, a qual indicou que a estrutura interna atende muitas áreas do conhecimento, porém para o ensino de Ciências ainda necessita ampliar espaços e recursos, destacando-se a falta de um laboratório de ciências, bem como aulas diferenciadas.

Conforme observado no gráfico 1, os alunos responderam em grande maioria que a estrutura interna disponibilizada pela escola é adequada e utilizada pela professora, no entanto indicaram a necessidade de um laboratório de Ciências. Evidenciando assim que a escola não proporciona ambientes diferenciados à professora desta disciplina, fazendo com que na falta de um laboratório ou sala própria para poder desenvolver materiais diferenciados com os alunos, a mesma deve buscar outros recursos para complementar sua aula.

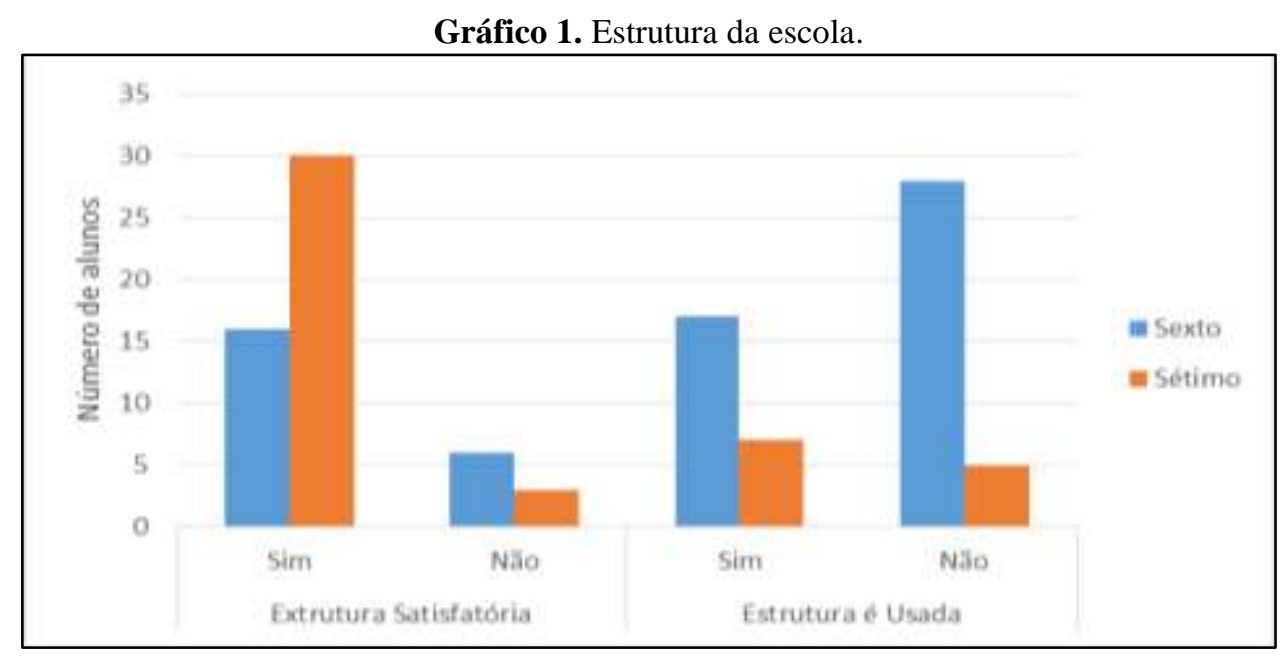

Por outro lado, a pesquisa realizada com a equipe técnica pedagógica proporcionou uma visão ampla dos aspectos que envolvem a relação escola, professor e pais, uma vez que exerce a função de criar uma via de ligação entre estes.

Como aspecto positivo, a equipe técnica pedagógica relatou que há com frequência a presença da mesma nos assuntos que circundam o educando, sempre quando necessário está puxando-o para possíveis conversas dos problemas que o envolvem e da mesma forma relatando ao professor e aos pais, pessoas fundamentais 
para a qualidade de ensino do aluno. Relatou também que a escola envolve-se com projetos relacionados à comunidade, uma vez que a mesma trabalha com o estímulo de princípios e valores aos educandos. Na relação equipe técnica pedagógica e professora, houve a percepção de confiança, pois a equipe fornece autonomia à professora em sala de aula. As respostas da equipe técnica pedagógica não se contradisseram em nenhum momento com as da professora, demonstrando que ambos utilizam da mesma linguagem.

Do contrário, a equipe técnica pedagógica relatou como aspectos negativos a deficiência na capacitação em geral dos educadores, que não recebem recursos da escola para o aprimoramento de habilidades especificamente relacionadas à inclusão social, tendo a escola o déficit de profissional que abrange esta questão.

As observações em sala de aula serviram como marco para a confecção do questionário voltado aos alunos, visto que, cada sala possuía uma maneira diferente de se comportar. As observações de como procederam às aulas e os comentários feitos pelos alunos, levaram a direcionar as questões para alguns pontos, no qual foi sentido defasagem.

Em relação às atualidades usadas pela professora em sala de aula, todos os alunos do sexto ano confirmaram em pesquisa que a mesma busca assuntos fora do livro didático para relacionar com as disciplinas propostas (conforme gráfico 2), contudo os alunos do sétimo ano negam o uso de atualidades pela professora.

Os alunos se contradizem quando se é perguntado sobre a utilização de outros recursos bibliográficos (apresentado também no gráfico 2), pois os mesmos informaram que a professora não faz uso de recursos além do livro didático. Em relação ao uso de outros recursos bibliográficos, houve contradições por talvez não levarem em conta que as temáticas que eles sentem falta de discutir em debates, possam vir de notícias em jornais, revistas e de outros recursos, complementando seu aprendizado. 
Gráfico 2. Recursos utilizados pela professora.

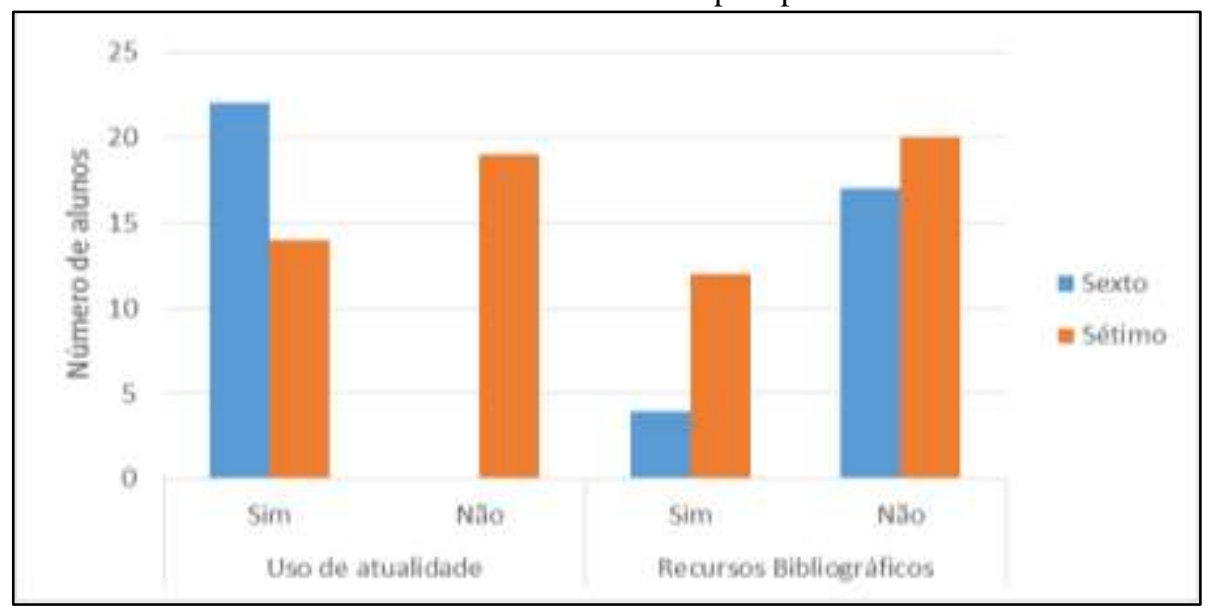

Nas turmas do sétimo ano, pouco mais da metade dos alunos afirmou que a professora não traz outras fontes de atualidades e recursos diferentes do livro utilizado pela escola, já a outra parcela de alunos afirmam o contrário.

Complementando com a discussão acima, o gráfico 3 apresenta alguns recursos considerados, pelos alunos, essenciais para aprimorar a aprendizagem. Nesta questão, os alunos puderam classificar em nível de um a quatro as opções que eram para assinalar por critério de grau de importância. Dentre os recursos indicados, os mais elencados pelo sétimo ano foram aulas dinâmicas e pelo sexto ano a aquisição de um laboratório de Ciências.

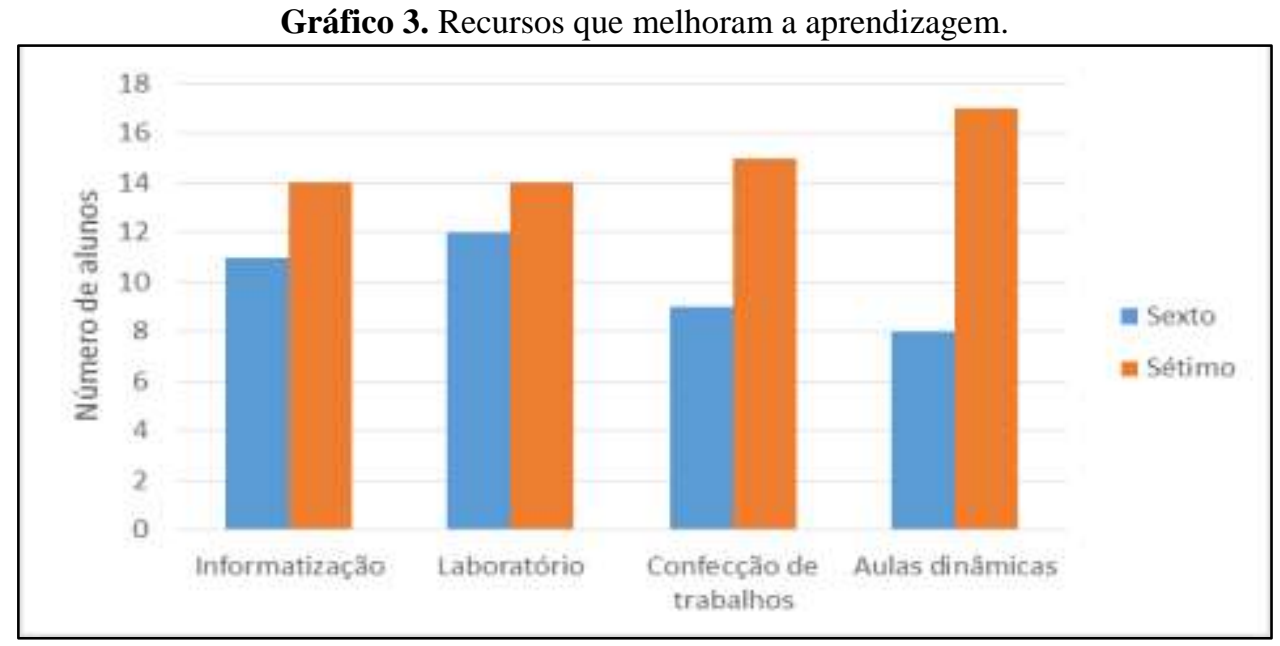

Enfim, a questão que deu o marco inicial para o projeto de extensão foi a questão relacionada aos temas que os alunos consideravam de interesse para ampliar 
seus conhecimentos. Conforme o gráfico 4, pode-se perceber os temas "animal", "meio ambiente" e "saúde", como principais assinalados pelas duas turmas.

Gráfico 4. Temas que necessitam ampliar os conhecimentos.

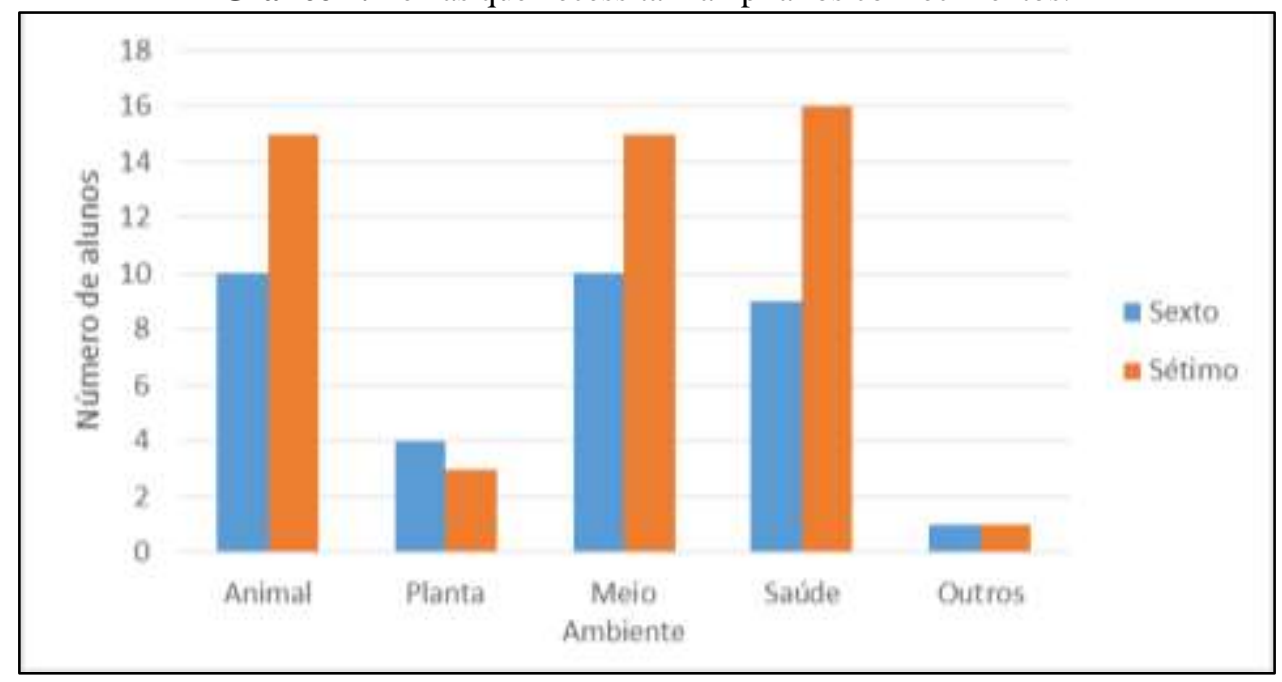

Visto que a escola já possui um projeto de educação ambiental, envolvendo animais e plantas, foi proposto o trabalho com a temática "saúde". Esse tema foi escolhido não só pelo questionário aplicado aos alunos, mais também através das observações das aulas, pelos comentários e conversa com a professora.

Com base nisto, e com a falta de espaço físico da escola para poder montar um ambiente de estudo para o ensino de Ciências, ressaltado como déficit pela professora e alunos, a proposta para a extensão de estágio foi desenvolver atividades dinâmicas, explorando outros recursos disponíveis pela escola, levando-os para fora da sala de aula, e conciliando este dinamismo com temas relacionados ao corpo humano.

\section{Atividades desenvolvidas e suas repercussões}

O projeto de extensão foi elaborado com relação à alimentação saudável, higiene e qualidade de vida, visando dinamizar as aulas de Ciências e mudar o conceito dos alunos sobre diversos mitos alimentares, ampliando seus conhecimentos sobre a área e ajudando-os a desenvolver atitudes que poderiam trazer benefícios a sua saúde.

No primeiro dia, 22 de maio, realizou-se uma palestra com as duas turmas sobre a temática proposta, porém em horários diferentes. A palestra ocorreu na sala de vídeo disponibilizada pela escola (figura 1), sendo utilizada uma apresentação de Power Point, que abordou assuntos sobre a alimentação saudável, hábitos de higiene, alimentação do aluno no dia-a-dia, benefícios das frutas e verduras, malefícios de alimentos e doenças 
que estes possam desenvolver. Nesta introdução, foi notável a surpresa dos alunos em relação à higiene e benefícios que as frutas podem trazer, sendo que muitos alunos não tinham ideia da importância de se lavar frutas como a banana ou a laranja, mesmo não comendo a casca.

Figura 1. Materiais utilizados na palestra.

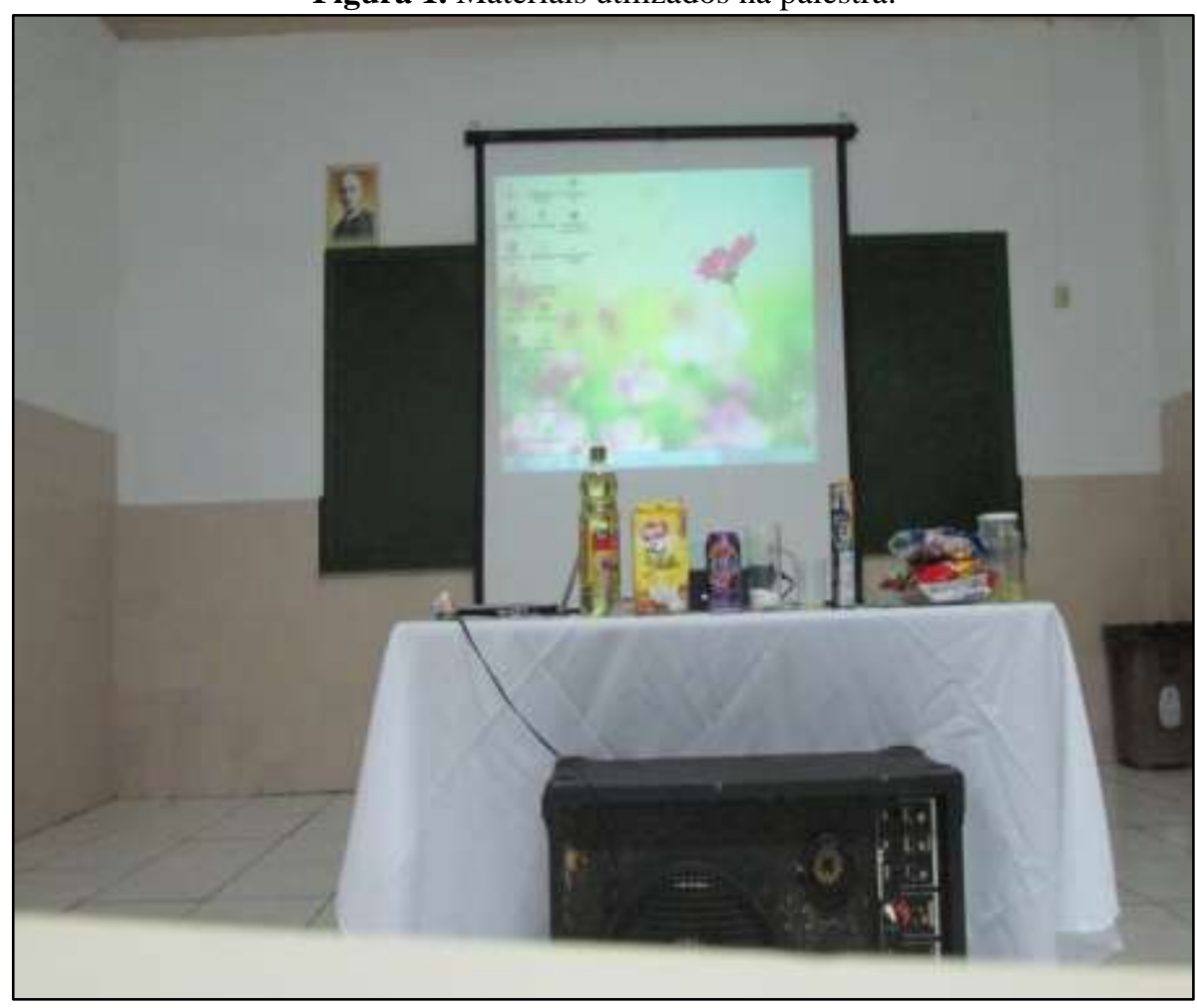

Fonte: das autoras.

Quando abordado a alimentação no cotidiano, foi realizada uma dinâmica, utilizando-se de um copo $180 \mathrm{ml}$ para representar à proporção que os ingredientes açúcar, sal e óleo possuem em diversos alimentos do dia-a-dia do aluno. O que deixou os alunos um pouco assustados em relação a sua alimentação, visto que muitos deles comiam alimentos citados como vilões todos os dias no recreio.

Por fim, ao passar um vídeo de motivação sobre alimentação saudável, cada aluno recebeu uma salada de fruta, condicionado em potinhos individuais com colherinhas para ser consumida, introduzindo o hábito saudável.

No dia 29 de maio, segundo dia do projeto, foram realizadas atividades diferentes com as duas turmas. No $6^{\circ}$ ano aplicou-se a dinâmica da teia alimentar, com o intuito de explorar a temática alimentação no ponto de vista das interações que ocorrem em diversas cadeias alimentares e a sua importância. Para isto, a equipe do projeto confeccionou plaquinhas com nomes de vários animais que constituíram uma teia 
alimentar, e, também, confeccionaram cartinhas para cada animal (figura 2), com a sua foto e informações importantes sobre eles, como tamanho do animal, habitat e tipo de alimentação. Os alunos foram direcionados ao pátio da escola, e divididos em quatro grupos dispuseram-se cada grupo com uma pessoa da equipe do projeto. Os alunos receberam explicações dos tipos de alimentação dos animais, e a forma como eles retiram também seus recursos necessários para poder sobreviver. Logo após, todos os alunos arrumaram-se em um círculo onde cada um recebeu uma plaquinha com um determinado animal sem repeti-los. Assim, com ajuda de uma linha os alunos começaram uma teia alimentar, passando a linha para o animal a qual predaria, participando todos. Esta atividade, além de complementar os conteúdos já abordados pela professora em sala de aula, pode levar os alunos a conhecer a alimentação de outros animais e a importância do nosso ecossistema para nossa própria sobrevivência, visto que os vegetais possuem um papel importante na base dessa cadeia.

Figura 2. Dinâmica teia alimentar.

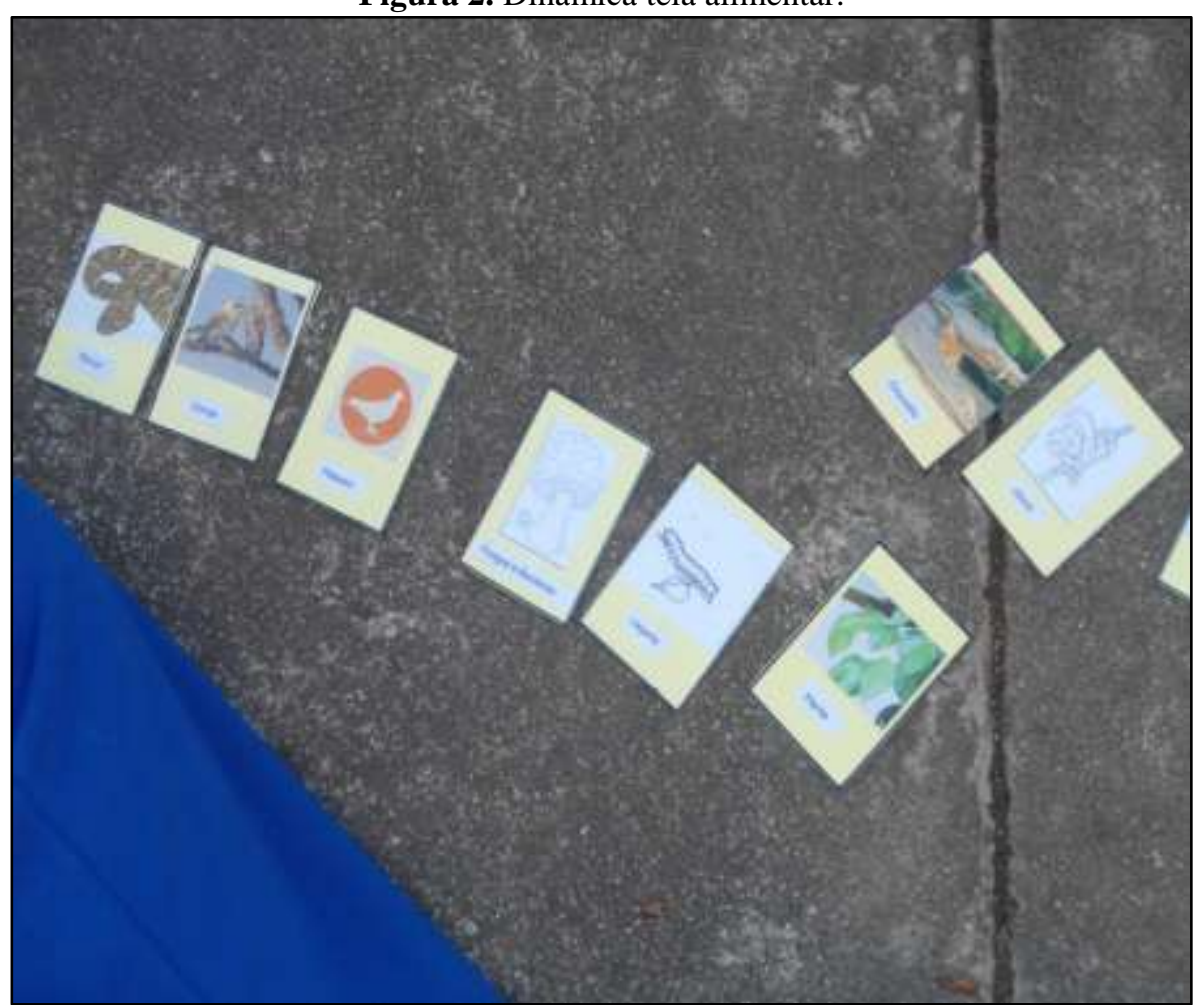

Fonte: das autoras.

Com o $7^{\circ}$ ano, neste mesmo dia, desenvolveu-se a gincana de conhecimento sobre alimentação. A atividade foi feita no pátio da escola, onde os alunos dividiram-se em quatro equipes. Cada equipe recebeu quatro plaquinhas, correspondente às quatro alternativas de resposta que cada pergunta teria (a, b, c, d). No total foram quarenta 
perguntas, que após serem lidas, os alunos tinham trinta segundos para levantar a plaquinha de resposta ao soar o apito. Cada resposta certa correspondia a um ponto, sendo feita à pontuação. As equipes escolheram um nome de fruta para representá-las, sendo a equipe manga a vencedora, recebendo um troféu (figura 3) em forma de árvore de frutas, confeccionada pela equipe do projeto. Utilizou-se um apito, uma prancheta para anotar as pontuações, um cronômetro e as plaquinhas de respostas. A gincana permitiu a equipe do projeto perceber quais assuntos os alunos mais fixaram e levaram para suas vidas.

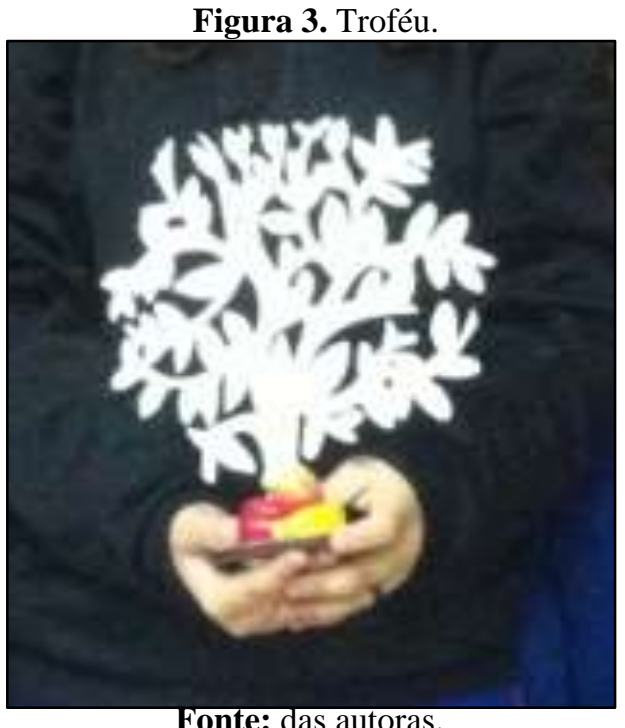

Fonte: das autoras.

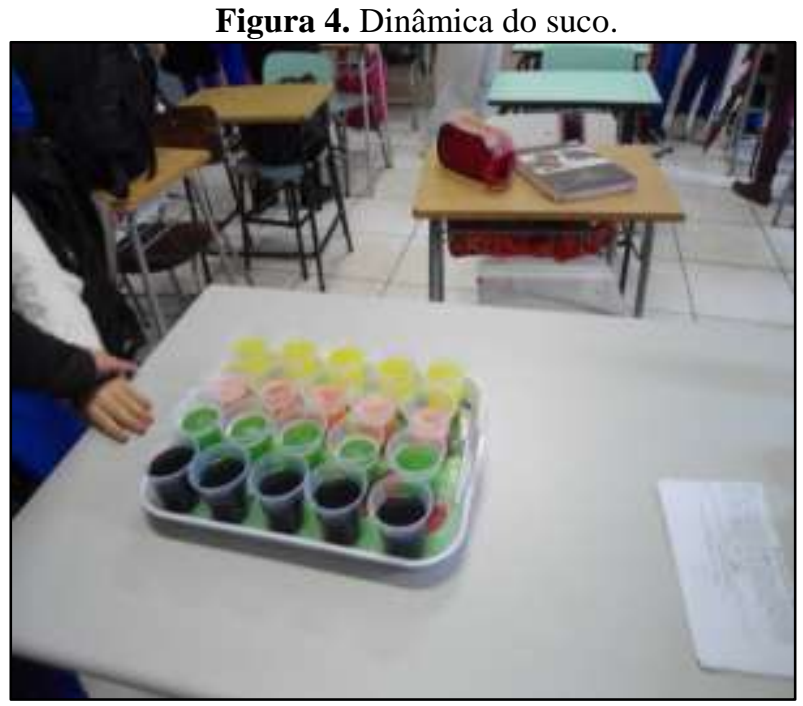

Fonte: das autoras.

O terceiro dia, 05 de junho, no $6^{\circ}$ ano aplicou-se a dinâmica do suco. No início houve a explicação sobre paladar, olfato e a visão, e suas influências na alimentação. Prepararam-se para esta dinâmica quatro sucos diferentes (figura 4) com aplicação de quatro cores de corantes, obtendo os sucos com um determinado sabor, mas com uma cor diferente. A turma permaneceu em sala onde se dividiu em quatro equipes. Cada equipe elegeu um representante que bebeu um suco de determinada cor. Sem poder falar aos colegas de equipe, o líder bebeu o suco e os colegas deram seus palpites de qual seria o sabor. Após todos os líderes dos grupos beberem e todas as equipes darem seus palpites, os líderes confessaram os sabores dos tipos de sucos, impressionando as equipes, que devido à cor opinaram ser um sabor diferente. Por fim, cada equipe provou o seu suco, aprendendo que a visão neste caso influenciou de maneira errada.

No mesmo dia, com o $7^{\circ}$ ano, nas mesmas equipes da gincana de conhecimentos, os alunos foram direcionados a observar a tabela nutricional de algumas embalagens de 
produtos (figura 5). Em seguida receberam uma tabela com algumas informações que deveriam retirar da embalagem, como prazo de validade aberto e fechado, quantidade que servia por porção, restrições como conter glúten ou com base em leite, e discutir se o alimento era saudável e quais malefícios que estes produtos poderiam trazer ao serem consumidos. Ao término da atividade, os alunos montaram uma refeição ideal, aprendendo a observar as informações que as embalagens trazem e a importância de ter uma alimentação balanceada.

Figura 5. Embalagens.

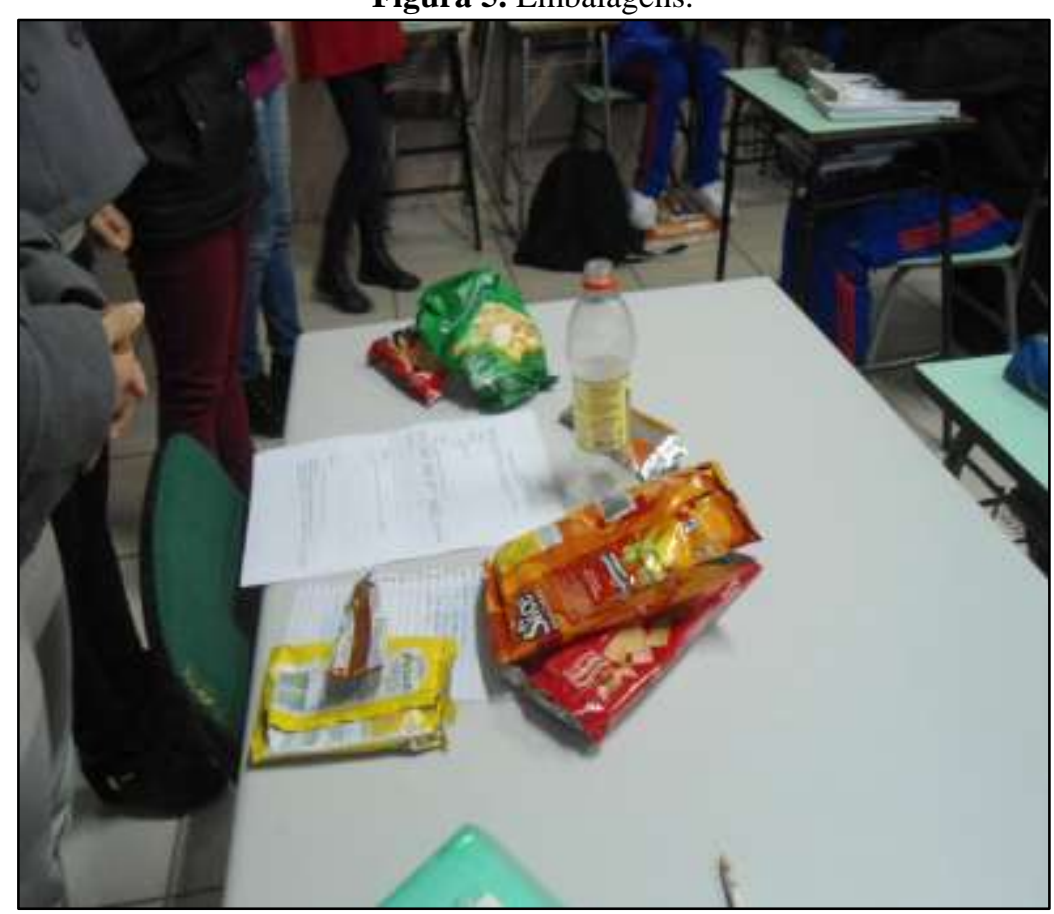

Fonte: das autoras.

\section{CONCLUSÃO}

O projeto de pesquisa e extensão possibilitou às acadêmicas do curso de Ciências Biológicas acessarem dados e observar aspectos importantes relativos ao ensino e aprendizagem de Ciências. Proporcionou também a observação da infraestrutura da escola e a exploração de outros recursos didáticos como forma de mecanismo facilitador do aprendizado.

As acadêmicas puderam analisar, através de um questionário, alguns métodos de ensino desenvolvido pela professora de Ciências, além de observar outras questões tão importantes quanto ao ensino em sala de aula, como a infraestrutura e a relação da equipe técnica pedagógica com o ensino. 
Como resultado da pesquisa, observou-se o déficit na infraestrutura, contudo, sem obtenção de recursos para contemplar a necessidade de um laboratório de Ciências, destacou-se outro aspecto relevante, como necessidade à construção de aulas diferenciadas.

Quanto a isto as acadêmicas desenvolveram uma série de atividades para dinamizar a temática alimentação, sendo este o tema gerado pela pesquisa. Entre as atividades desenvolvidas destacaram-se as dinâmicas da teia alimentar e gincana dos conhecimentos, por onde os alunos interagiram entre si e puderam refletir sobre o conteúdo, aprendendo através de brincadeiras e mostrando que todo o conteúdo abordado foi por eles aprendido, tornando-se gratificante, pois assim cumpriu-se o objetivo da extensão estabelecido pelo projeto, o de despertar o interesse dos alunos através da motivação proporcionada pelas atividades diferenciadas.

Assim, com a utilização de recursos didáticos diferenciados para trabalhar a temática alimentação, percebeu-se que para todos os envolvidos, alunos, professora e acadêmicas, houve maior facilidade em construir o conhecimento essencial sobre o assunto, bem como forneceu a experiência de que atividades diferenciadas motivam os alunos a aprender, contribuindo para a sua formação.

\section{REFERÊNCIAS}

ANTUNES, Celso. Professores e professauros: reflexões sobre a aula e práticas pedagógicas diversas. 2. ed. Petrópolis, RJ: Vozes, 2008.

CANDAU, Vera Maria (Org.). Didática, currículo e saberes escolares. 2 ed. Rio de Janeiro: DP\&A, 2002.

DELIZOICOV, Demétrio. Ensino de Ciências: fundamentos e métodos. São Paulo: Cortez, 2002.

FREIRE, Paulo. Pedagogia da autonomia: saberes necessários da prática educativa. 25 ed. São Paulo: Paz e Terra, 1996.

LIBÂNEO, José Carlos. Educação escolar: políticas, estruturas e organização. São Paulo: Cortez, 2003.

SANTOS, Heliete Rocha dos. Projeto Arte e educação ambiental: uma experiência. 2 ed. Criciúma: FAVI - UNESC- FNMA, 1998. 